\title{
Practical strategies to reduce nosocomial transmission to healthcare professionals providing respiratory care to patients with COVID-19
}

Ramandeep Kaur ${ }^{1}$, Tyler T. Weiss ${ }^{1}$, Andrew Perez ${ }^{1}$, James B. Fink ${ }^{1}$, Rongchang Chen ${ }^{2}$, Fengming Luo ${ }^{3}$, Zongan Liang ${ }^{3}$, Sara Mirza ${ }^{1}$ and Jie Li ${ }^{1 *}$ (i)

\begin{abstract}
Coronavirus disease (COVID-19) is an emerging viral infection that is rapidly spreading across the globe. SARS-CoV-2 belongs to the same coronavirus class that caused respiratory illnesses such as severe acute respiratory syndrome (SARS) and Middle East respiratory syndrome (MERS). During the SARS and MERS outbreaks, many frontline healthcare workers were infected when performing high-risk aerosol-generating medical procedures as well as when providing basic patient care. Similarly, COVID-19 disease has been reported to infect healthcare workers at a rate of $\sim 3 \%$ of cases treated in the USA. In this review, we conducted an extensive literature search to develop practical strategies that can be implemented when providing respiratory treatments to COVID-19 patients, with the aim to help prevent nosocomial transmission to the frontline workers.
\end{abstract}

Keywords: Nosocomial infection, Respiratory care, Aerosol-generating procedures

\section{Introduction}

Coronavirus disease (COVID-19) cases were first reported to the World Health Organization on December 31, 2019 [1]. Since then, this illness has spread exponentially in over 200 countries. As of June 9, 2020, there were 7,039,918 confirmed cases of the COVID-19 disease globally [2]. Even though the exact mode of COVID-19 transmission has been debatable, the route of COVID-19 transmission is reported to be from personto-person contact and exposure to respiratory droplets $(>5-10 \mu \mathrm{m})$ [3], whereas airborne transmission $(<5 \mu \mathrm{m})$

\footnotetext{
* Correspondence: Jie_Li@rush.edu

Prior abstract publication/presentation: $\lrcorner$ presented partial content in the special COVID-19 webinar invited by the International Society for Aerosols in Medicine on March 19, 2020.

'Division of Respiratory Care, Department of Cardiopulmonary Sciences, Rush University Medical Center, 1620 W Harrison St, Tower LL1202, Chicago, IL 60612, USA

Full list of author information is available at the end of the article
}

during aerosol-generating procedures remains under investigation $[4,5]$. Based on the initial data reported [612], around 5-30\% of COVID-19 patients develop signs of severe respiratory distress requiring intensive care unit (ICU) admission to receive advanced respiratory support in terms of oxygen therapy, non-invasive and invasive ventilatory support with prone positioning (Table 1).

Standard droplet and contact precautions (gowns, gloves, mask) are known to reduce the risk of contracting severe acute respiratory syndrome (SARS) [13] but not under all circumstances, especially when performing high-risk procedures such as intubation [14]. A recent systematic meta-analysis showed that a physical distance of $1 \mathrm{~m}$ or more and wearing a mask is optimum to reduce person-to-person virus transmission and to keep healthcare workers (HCWs) from contracting the SARSCoV-2 infection [15]. During the SARS outbreak, many 


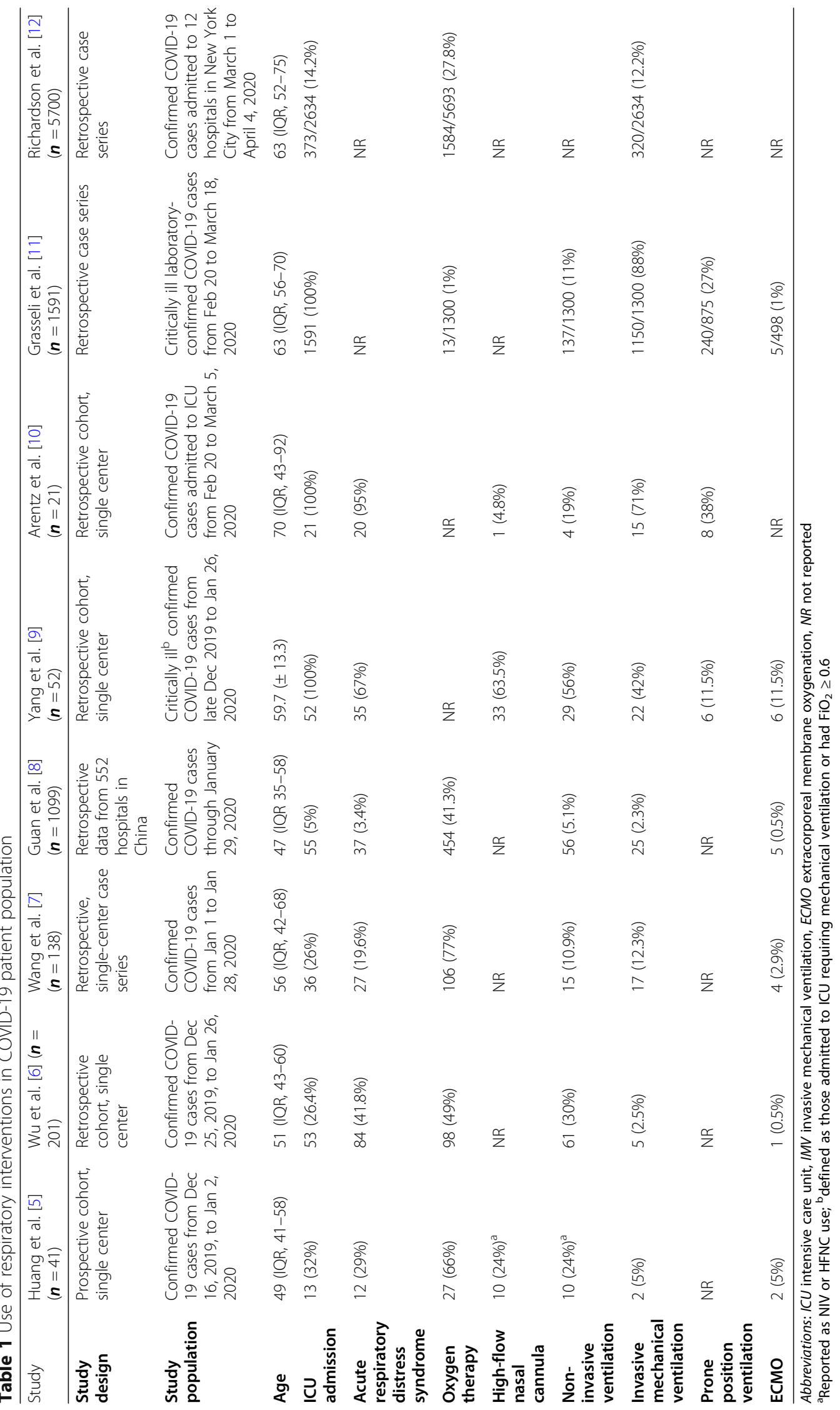


frontline HCWs were infected via nosocomial transmission due to failure to implement adequate infection control precautions, especially when performing aerosolgenerating medical procedures (AGMPs) [16-18], such as bronchoscopy, intubation, suctioning, invasive and non-invasive ventilation (NIV), bag mask ventilation, and nebulization [19-21]. In a prospective study, Macintyre et al. [22] reported that clinicians who performed AGMPs were at greater risk of acquiring the infection as compared to those who were not involved in such procedures [adjusted relative risk (RR) 2.90, 95\% confidence interval (CI) 1.42-5.87]. Considering SARS-CoV-2 belongs to the same family as SARS, frontline clinicians delivering AGMPs to COVID-19 patients are likely at a similar high risk of transmission and infection. According to the Centers for Disease Control and Prevention (CDC), 95,860 (incidence of $3 \%) \mathrm{HCW}$ s have been reported to be infected with COVID-19 in the USA, with at least 515 deaths as of July 10, 2020 [23]. Until further high-quality evidence, including well-conducted randomized controlled trials, is available to demonstrate the definite role of AGMPs in spreading nosocomial infection, it is best to use the data available from past outbreaks to implement additional safeguards.

In this review, we performed a comprehensive literature search to present practical strategies (Table 2) to reduce the risk of nosocomial transmission when delivering AGMPs to patients with COVID-19. These suggestions are to be utilized in addition to the CDC recommendations available for proper personal protective equipment (PPE) for HCWs.

\section{Literature search strategy}

A literature search was performed via PubMed and Scopus databases using the following keywords: ("coronavirus" OR "COVID-19" OR "Severe Acute Respiratory Syndrome" OR "SARS" OR "Middle East Respiratory Syndrome" OR "MERS" OR "H1N1") AND ("aerosol generating procedures" OR "nosocomial infection"). Publication types included systematic review, meta-analysis, randomized clinical trials, and observation studies. The study population involved HCWs providing respiratory care including AGMPs to patients infected with SARS, MERS, influenza A virus subtype H1N1 (H1N1), or COVID-19. In vitro studies investigating the role of exhaled air dispersion when providing AGMPs were also included. Published letters, book chapters, conference abstracts, and editorials were excluded. The literature search was limited to articles published until May 2020. The detailed selection process conducted is shown in Fig. 1.

\section{Literature findings and suggestions}

A common clinical finding with COVID-19 is cough [7]. Coughing, speaking, laughing, and breathing have been associated with generation of bio-aerosols capable of carrying the virus $[46,47]$. The bio-aerosols can range from 0.1 to $100 \mu \mathrm{m}$, and particles smaller than $1 \mu \mathrm{m}$ have been reported to disperse to greater distances and remain airborne for several hours [5, 48, 49]. Large particles tend to settle directly on surfaces surrounding the patients, with reports of surface swabs testing positive across the patient's room $[5,50]$. A recent experimental study indicated that the COVID-19 virus can remain viable and infectious in aerosol for hours and on surface for days [51] and virus-laden aerosol deposition plays a role in surface contamination [4]. Some medical procedures that cause/irritate patients to cough or sneeze, such as bronchoscopy and nasal-pharyngeal suctioning, lead to the generation of bio-aerosols from patients. In contrast, other medical procedures do not "generate" bio-aerosols but increase the dispersion of bio-aerosols generated by infectious patients, such as NIV and highflow nasal cannula (HFNC) oxygen therapy [5, 19]. Based on CDC guidelines, HCWs performing AGMPs should wear N95 or high-level respirators along with eye protection, gloves, and a gown. Furthermore, the number of personnel entering patient's room during AGMPs should be limited and procedures should be ideally performed in an airborne infection isolation room [52].

\section{Oxygen therapy}

Supplemental oxygen therapy is essential for patients with hypoxemic respiratory failure. While supplemental oxygen has not been shown to generate bio-aerosols, they may have a role in dispersing them. In an in vitro study using a human simulator with smoke $(<1 \mu \mathrm{m}$ aerosol of solid particles) exhaled through airway, Hui et al. examined the exhaled air dispersion during oxygen delivery via nasal cannula. The results showed that exhaled air dispersion increased as oxygen flow was increased from 1 to $5 \mathrm{~L} / \mathrm{min}$ and substantial exposure occurred within $1 \mathrm{~m}$ from the bed in a negative pressure ventilation room [24]. A substantial increase in lateral exhaled air dispersion is reported as the oxygen flows increased [25-27]. The same group of researchers using a similar model reported that both nonrebreather and air-entrainment masks increased exhaled air dispersion [25-27]. Exhaled air dispersion distance was further with the air-entrainment mask than simple and nonrebreather masks [53].

Placing a simple surgical mask on patient's face has been reported to reduce the exhaled dispersion distance $[28,29]$ and the influenza A virus load [30] during a cough. Surgical masks and N95 masks are similarly effective at preventing influence virus exposure [30]. 
Table 2 Recommendations for providing respiratory care to COVID-19 patients

\begin{tabular}{|c|c|c|c|}
\hline & Respiratory intervention & Evidence resource & Recommendation \\
\hline 1 & Oxygen therapy & $\begin{array}{l}5 \text { in vitro }[24-28] \\
3 \text { in vivo }[29-31]\end{array}$ & $\begin{array}{l}\text { - Use nasal cannula and place a surgical/procedure mask on the patient's face } \\
\text { - Avoid Venturi mask } \\
\text { - Avoid nonrebreather mask unless it is filtered }\end{array}$ \\
\hline 2 & High-flow nasal cannula & $\begin{array}{l}1 \text { in vitro }[32] \\
2 \text { in vivo }[15,31]\end{array}$ & $\begin{array}{l}\text { - Proper nasal cannula fitting } \\
\text { - Place a surgical/procedure mask over HFNC on the patient's face (Fig. 2) }\end{array}$ \\
\hline 3 & Nebulization & $\begin{array}{l}2 \text { in vitro }[33,34] \\
2 \text { in vivo }[22,35]\end{array}$ & $\begin{array}{l}\text { - Use metered dosed inhaler with spacer when possible } \\
\text { - Avoid using small volume nebulizer unless it is filtered (Fig. 3a, b) } \\
\text { - Use nebulizer in line with HFNC or via ventilator }\end{array}$ \\
\hline 4 & $\begin{array}{l}\text { Lung expansion and airway } \\
\text { clearance therapy* }\end{array}$ & 3 in vivo $[22,35,36]$ & $\begin{array}{l}\text { - If using IPPB, place a filter between circuit and mask or mouthpiece, or on } \\
\text { expiratory port } \\
\text { - If possible, avoid cough inducing therapies such as intermittent percussive } \\
\text { ventilation and cough assist } \\
\text { - During high-frequency chest wall oscillation therapy, place a surgical/ } \\
\text { procedure mask on the patient's face }\end{array}$ \\
\hline 5 & Non-invasive ventilation* & $\begin{array}{l}2 \text { in vitro }[37,38] \\
2 \text { in vivo }[39,40]\end{array}$ & $\begin{array}{l}\text { - Use tight fit oral mask without leaks, consider helmet or total face mask } \\
\text { if available } \\
\text { - Avoid using nasal mask } \\
\text { - When using non-heated-wire single-limb circuit, place a filter between } \\
\text { the non-vented mask and the expiratory port (Fig. 4a) } \\
\text { - If humidification is required, heated wire single-limb circuit with filter } \\
\text { placed at the expiratory port for non-invasive ventilator (Fig. 4b) or heated } \\
\text { wire dual-limb circuits with critical care ventilator can be utilized }\end{array}$ \\
\hline 6 & $\begin{array}{l}\text { Intubation and Invasive } \\
\text { ventilation* }\end{array}$ & $\begin{array}{l}1 \text { in vitro }[41] \\
4 \text { in vivo }[22,39,42,43]\end{array}$ & $\begin{array}{l}\text { - During bag mask ventilation, place a filter between the mask and resuscitation } \\
\text { bag (Fig. 5) } \\
\text { - Most experienced provider performs intubation } \\
\text { - Use video-laryngoscope } \\
\text { - Rapid sequence intubation } \\
\text { - Avoid breaking the ventilator circuit }\end{array}$ \\
\hline 7 & Ventilator weaning & & $\begin{array}{l}\text { - Avoid cool aerosol for tracheostomy patient, instead use HME. If the patient } \\
\text { needs frequent suctioning (more than once every hour), place an in-line suction } \\
\text { catheter with T-piece connected to cool aerosol or heated humidification, } \\
\text { the other end of T-piece connected to a filter (Fig. 6). Additionally, if the } \\
\text { patient has cuffless tracheotomy, place a procedure mask on patient's face } \\
\text { - Avoid using T-piece trials. If needed, use the setup with a filter described above }\end{array}$ \\
\hline 8 & Extubation* & & $\begin{array}{l}\text { - When removing the endotracheal tube, simultaneously turn off the ventilator } \\
\text { - Avoid disconnecting ETT from the ventilator circuit before extubation to reduce } \\
\text { spray of contaminated aerosols }\end{array}$ \\
\hline 9 & Transport & & $\begin{array}{l}\text { - Place a filter between the artificial airway and the transport ventilator circuit } \\
\text { - Use HME that has filter function (HME-F) } \\
\text { - Consider clamping the ETT before disconnection from ventilator circuit }\end{array}$ \\
\hline 10 & Bronchoscopy assist* & 2 in vivo $[44,45]$ & $\begin{array}{l}\text { - For spontaneously breathing patients, place a surgical mask on patient's face (Fig. 7a, b) } \\
\text { - Use NIV mask with examination port for patients on NIV (Fig. 7d) } \\
\text { - Use swivel adapter to insert bronchoscope for intubated patient (Fig. 7c) }\end{array}$ \\
\hline
\end{tabular}

Abbreviations: HFNC high-flow nasal cannula, IPPB intermittent positive pressure breathing, HME heat moisture exchanger, ETT endotracheal tube, NIV non-invasive ventilation

*Based on CDC guidelines, these procedures should ideally be performed in airborne infection isolation rooms

Placing either mask on a patient with confirmed COVID-19 can help reduce the dispersion of bio-aerosols [15]. Based on these findings, when a standard nasal cannula is used to deliver low-flow oxygen therapy, a surgical mask should be placed over the patient's face. The air-entrainment mask should be avoided for patients with COVID-19, if possible. If higher delivered $\mathrm{F}_{\mathrm{I}} \mathrm{O}_{2}$ is needed, a closed non-breather mask with a filter could be considered [54].

Oxygen delivery via HFNC has become widely used in patients with acute hypoxemic respiratory failure due to its benefits of meeting or exceeding patient inspiratory flow demand, reducing oxygen dilution, and washing out pharyngeal dead space [55]. HFNC has been shown to reduce the need for endotracheal intubation when compared to conventional oxygen delivery devices [56]. Two retrospective studies examining the effects of HFNC in patients with acute hypoxemic respiratory failure secondary to COVID-19 showed that HFNC was able to maintain adequate oxygenation and reduced the need for NIV and mechanical ventilation [32, 57]. Exhaled smoke dispersion, from a manikin during HFNC treatment, was shown to significantly increase with increased flow rate [58]. Interestingly, the dispersion distance from the HFNC at $60 \mathrm{~L} / \mathrm{min}$ was shorter than an air- 


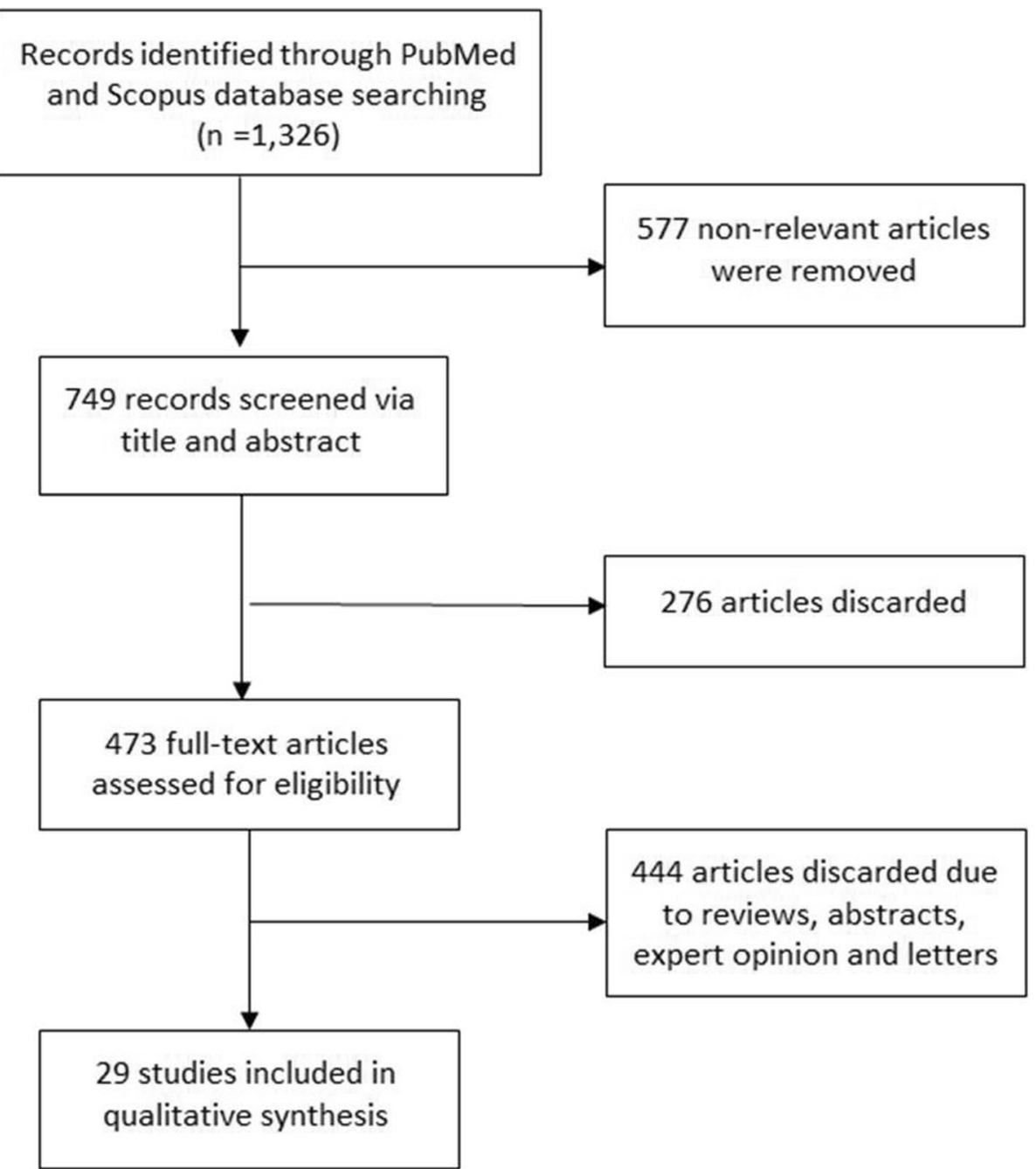

Fig. 1 Flow diagram of the literature search

entrainment or nonrebreather mask [53]. A randomized controlled, crossover non-inferiority study trial reported no difference in gram-negative bacterial and total bacterial counts between HFNC at $60 \mathrm{~L} / \mathrm{min}$ and simple oxygen mask at $8 \mathrm{~L} / \mathrm{min}$ when air sample collection plates were placed at 0.4 or $1.5 \mathrm{~m}$ away from the patient [31]. It is important to note that a substantial increase of exhaled smoke dispersion was reported when the nasal cannula connection with patient nares was loose [58, 59]. Because of these findings, it is suggested that a surgical or procedure mask be worn by patients receiving HFNC (Fig. 2). Regular checks on the proper position and connection of the nasal cannula interface under the mask are also necessary.

\section{Nebulization}

Aerosol therapy has been identified as a high-risk procedure for nosocomial transmission, due to its active generation of aerosol, which may carry viruses into the environment $[19,60]$. Hui and colleagues found the maximum exhaled air dispersion distance was $\geq 0.45 \mathrm{~m}$ when a small volume jet nebulizer (SVN) was connected to a mask at a gas flow of $6 \mathrm{~L} / \mathrm{min}$ [33]. This distance was even further than NIV at maximum settings (IPAP $18 \mathrm{cmH}_{2} \mathrm{O}$, EPAP $4 \mathrm{cmH}_{2} \mathrm{O}$ ), using the same study method [33]. Two clinical observational studies also found droplet counts significantly increased immediately after SVN started to generate aerosol, particularly, the aerosol/droplet count within small and medium size range $1-5 \mu \mathrm{m}$, when compared to the baseline level or other procedures including oxygen therapy and NIV [35] or bronchoscopy examination [44]. Nevertheless, the aerosol/droplets generated by a nebulizer may not contain a virus; however, if the nebulizer is contaminated, the aerosol can carry viruses to the surrounding environment. McGrath and colleagues [34] found that mass 


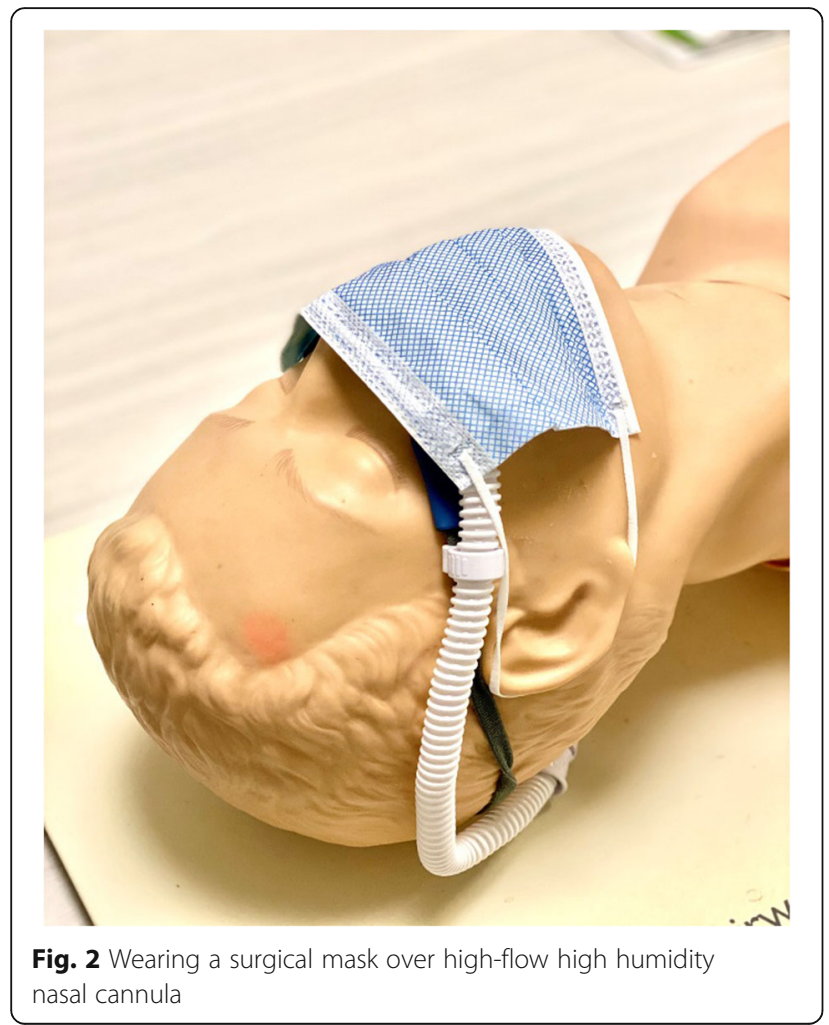

concentrations of aerosols/droplets were significantly reduced after placing a filter at the end of the mouthpiece for nebulizers. Therefore, if aerosol therapy is indicated for COVID-19 patients, SVN should be avoided unless filtered, and inhalers including metered dose inhaler (MDI) and dry power inhalers (DPIs) are preferred for spontaneous breathing patients who can tolerate their use without generating additional cough [61].

With MDI, a spacer with one-way valve is suggested to reduce the need for coordination and to increase lung deposition [62]. If patients are unable to use MDIs or DPIs, or the required medication is only available in the form of a solution, such as antibiotics, antivirals, mucokinetics, or prostanoids, nebulizers via mouthpiece with a filter placed distal to the reservoir tubing (Fig. 3a and b) should be utilized. For patients who cannot tolerate a mouthpiece or require medication administered over a prolonged period of time, such as continuous bronchodilator for asthmatic patients [63] or inhaled epoprostenol for patients with pulmonary hypertension or hypoxemia [64, 65], in-line placement of a nebulizer with HFNC setup is recommended. This setup has two advantages: (1) more comfortable and better tolerated when compared to a mask or mouthpiece [63] and (2) a surgical mask to reduce the aerosol dispersion distance or aerosol mass concentration can be placed on the patient $[53,56]$. When HFNC is utilized to deliver aerosol treatment, gas flow needs to be set relatively low if possible $(10-20 \mathrm{~L} / \mathrm{min}$ for adults and $0.25 \mathrm{~L} / \mathrm{kg} / \mathrm{min}$ for children), to improve the aerosol delivery efficiency $[66,67]$ and reduce the dispersion. Vibrating mesh nebulizers or valved T-pieces for jet SVNs can reduce the need to break the ventilator circuit when nebulization is provided during invasive ventilation.

\section{Lung expansion and airway clearance therapy}

Little evidence is available regarding lung expansion therapy and nosocomial infection. Lung expansion therapy is designed to treat and prevent pulmonary atelectasis. Intermittent positive pressure breathing (IPPB) utilizes short-term positive pressure ventilation via mask or mouthpiece to promote lung expansion. Due to the risk of causing a cough response that might disperse bio-aerosols [21], IPPB should be used judiciously and with filters placed between the breathing circuit and the mask or mouthpiece.
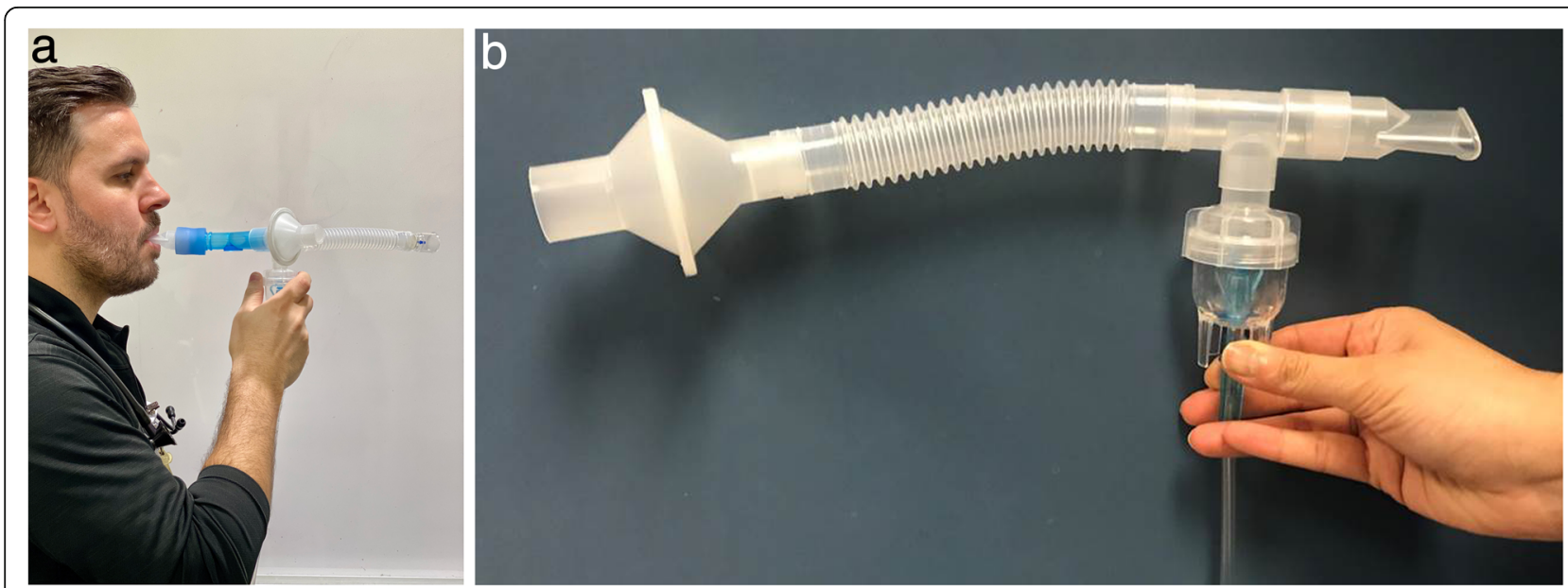

Fig. 3 a SVN setup with filter and one-way valve. b SVN setup with a filter 

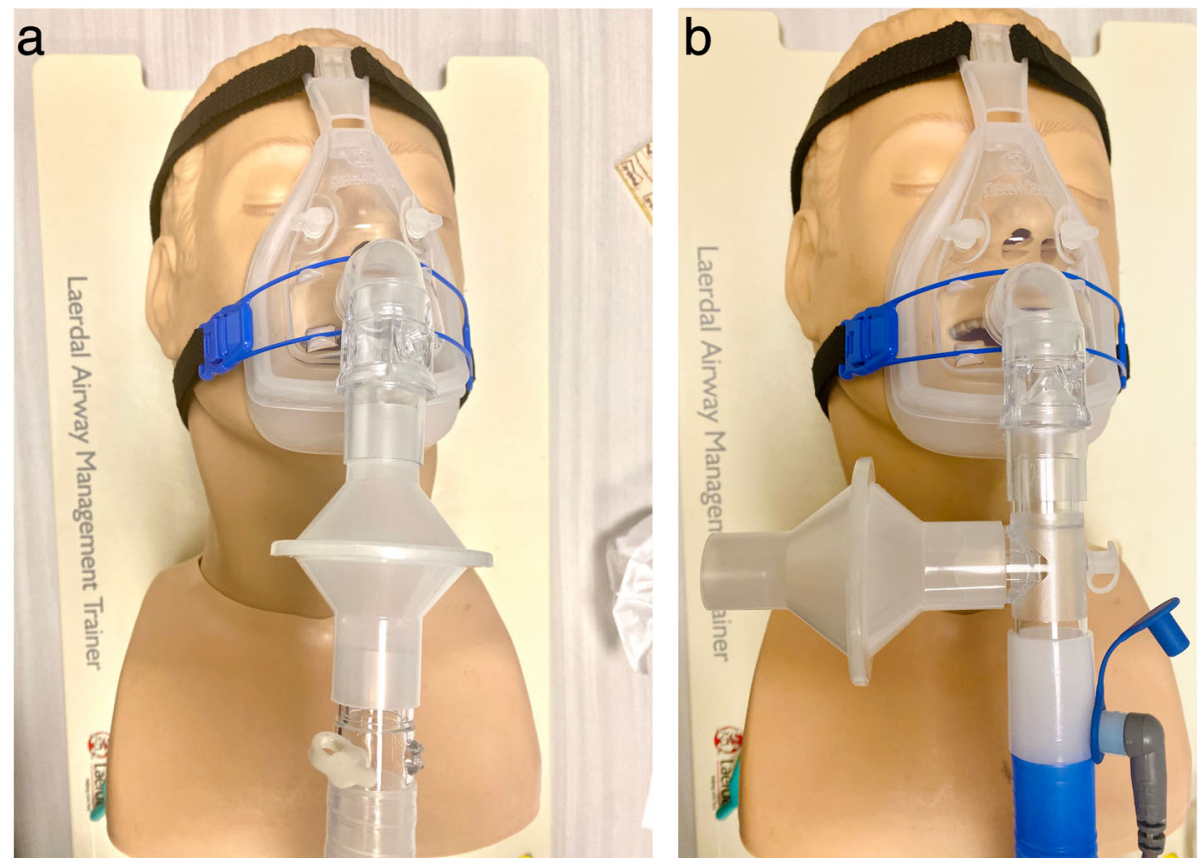

Fig. 4 a Non-heated single limb ventilator circuit. b Heated single limb ventilator circuit

The number of particles emitted by cough from an infected patient was greater than that from a recovered patient $(P<0.001)$ [36]. Bronchial hygiene therapies such as intermittent percussive ventilation and vibratory positive expiratory pressure irritate the airway causing the patient to cough forcefully, potentially emitting virusladen aerosols. Placing a filter between these devices and patient's mouth is suggested. When intermittent percussive ventilation is utilized, nebulization via its integrated nebulizer should be avoided as the filter placed between the device outlet and patient will capture aerosols. Additionally, high-frequency chest wall oscillation can be used for secretion clearance. In addition to HCWs wearing proper PPE, a surgical or procedure mask worn by patients receiving the therapy may be helpful. Overall, in patients with confirmed COVID-19, avoid the indiscriminate use of bronchial hygiene therapies that may not be clinically indicated [61].

\section{Non-invasive ventilation}

NIV has been utilized in 10-50\% of COVID-19 patients in published clinical reports [6-12]. Even though NIV delivered by helmet was effective in terms of reducing intubation rate and 90-day mortality rate among ARDS patients [68], its role in patients with severe ARDS remains controversial [69]. During the MERS outbreak, NIV was commonly used to treat acute hypoxic respiratory failure, but it had a high failure rate and was not associated with improved patient outcomes [70].
NIV produces a jet of exhaled gas through the exhalation port or leak from the connection of patient's interface and ventilator, increasing dispersion distance of patient-generated bio-aerosol, and therefore it is counted as an AGMP [20, 39]. Consequently, NIV should be used with caution for COVID-19 patients and additional modifications to minimize or reduce exhaled gas/aerosol dispersion are required.

In an experimental study, Hui et al. reported significant exhaled air dispersion within a $0.5-\mathrm{m}$ radius of the human simulator receiving NIV and higher pressure settings increased the spread of exhaled air. However, the exhaled air dispersion is limited if the mask fit is appropriate [37]. When comparing helmet to total face mask, Hui et al. [38] in another study demonstrated that NIV application via a double-limb circuit ventilator with filters and a helmet with good seal was effective in reducing exhaled air dispersion. In contrast, NIV applied via a total mask through a single-limb circuit ventilator caused increased exhaled air dispersion [38]. Non-vented masks were shown to have less air dispersion as compared to vented mask [71].

Thus, when vented masks are used, additional precautions for protection of the $\mathrm{HCW}$ may be appropriate. HCWs that are in close proximity to patients receiving NIV need to wear high respiratory personal protection including N95 or powered air-purifying respirator (PAPR). Secondly, the NIV circuits can be modified to place a filter. During the SARS outbreak, Cheung et al. demonstrated that a filter placed before the fixed 


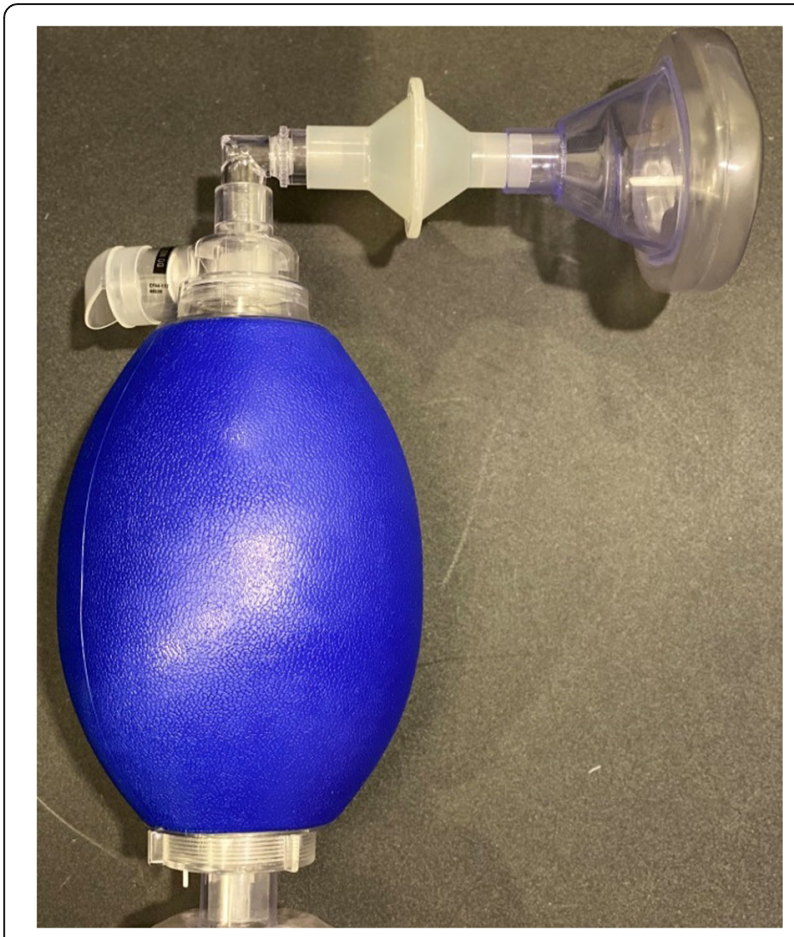

Fig. 5 Resuscitation bag setup with a filter

exhalation port in the single-limb circuit was effective in reducing the incidence of nosocomial transmission among HCWs [40]. However, due to the lack of a control group, the results of this study should be interpreted cautiously. Additionally, Simonds et al. showed that modifying NIV circuit with a filter was effective in reducing the droplet counts [35]. Thus, a filter should be placed between the non-vented mask and the exhalation port to reduce environmental contamination of bioaerosols (Fig. 4a). Notably, humidification should be avoided in this type of circuit as the viral filter may capture water vapor in the circuit, resulting in occlusion for exhalation. If humidification is necessary, a modified exhalation port is needed to place a filter at the outlet (Fig. 4b). An alternative is using a dual-limb circuit ventilator with filters to deliver NIV. This would allow for both humidification and the reduction in exhaled gas/ aerosol dispersion.

Regardless of interface/ventilator, the risk of a leak between the patient and the mask interface cannot be overlooked. Choosing an appropriate interface size and type, along with the appropriate circuits and ventilators, is crucial. A good fitting oral mask is preferred and avoid using a nasal mask for patients with COVID-19. If unable to get a good seal with an oral mask, consider using a total face mask or a helmet, if available.

\section{Intubation and mechanical ventilation}

Clinicians who perform or assist in endotracheal intubation are directly exposed to patient's lower airway where high concentrations of virus is accumulated. Additionally, in patients with an intact cough or gag reflex, intubation may increase exhaled air dispersion [72]. Therefore, intubation is considered high risk [73]. The risk of being infected when performing or assisting intubation (RR, 13.29; 95\% CI, 2.99-59.04; $p=0.003$ ) was found in the outbreak of SARS in a Canadian ICU [39]. Since then, high levels of PPE and negative pressure environments have been recommended to protect clinicians during intubation [74]. To reduce the exposure

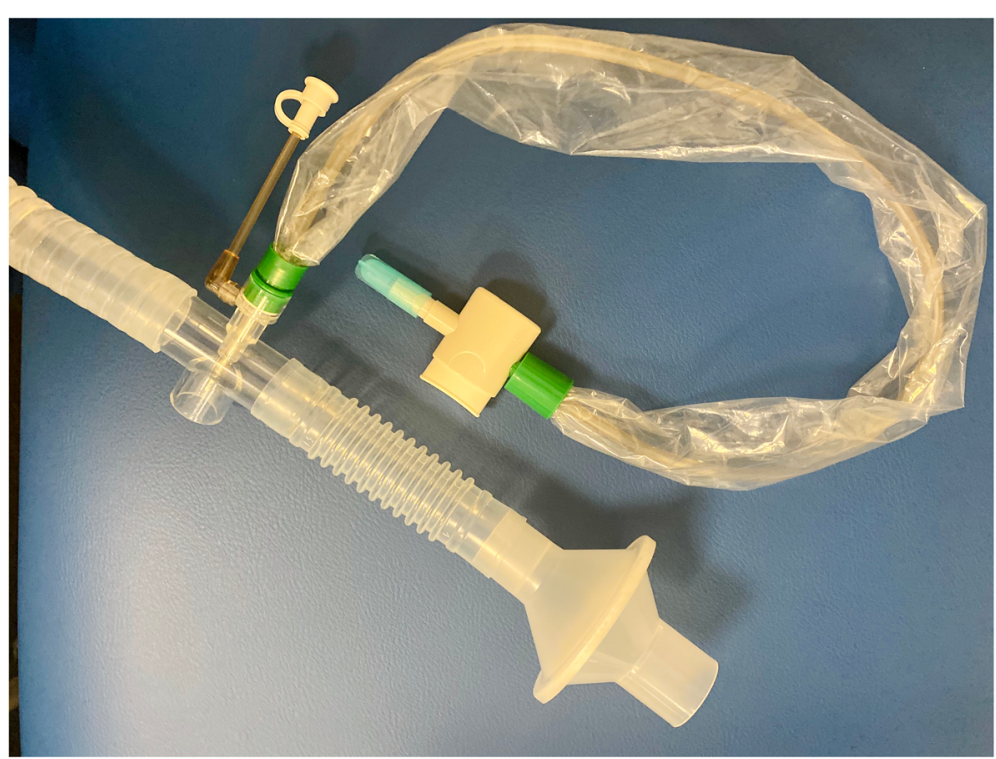

Fig. 6 T-piece setup for tracheostomy patients 
time to the SARS-CoV-2, the most experienced provider should perform intubation to avoid multiple attempts. Video-laryngoscope has shown to be useful when intubating patients with COVID-19 to increase the distance between the provider and the patient airway [74]. For a difficult airway, bronchoscopy is preferred to assist intubation, if a skilled provider is present [75]. Rapid sequence intubation is also recommended, in order to minimize cough during the procedure [42, 76]. Aerosol boxes [77] as well as protective shields made of glass [78] have been described as practical barriers to limit exposure to patient's exhaled droplets during intubation. While potentially useful, a documented reduction in disease transmission has not been reported and concerns regarding adequate airway view and appropriate ergonomics during intubation have been raised [79].

Pre-oxygenation prior to intubation plays a crucial role in avoiding complications during intubation. Multiple randomized controlled trials have shown that the utilization of HFNC for pre-oxygenation can help reduce the incidence of hypoxemia during intubation $[55,80]$. The cost-effectiveness and the high risk of transmission from high gas flows should be taken into consideration before using it for pre-oxygenation prior to intubation. The traditional method of using manual ventilation via resuscitator and mask for patients prior to intubation also has some risks. Exhaled gas dispersion distance has been shown to be $16-27 \mathrm{~cm}$ during
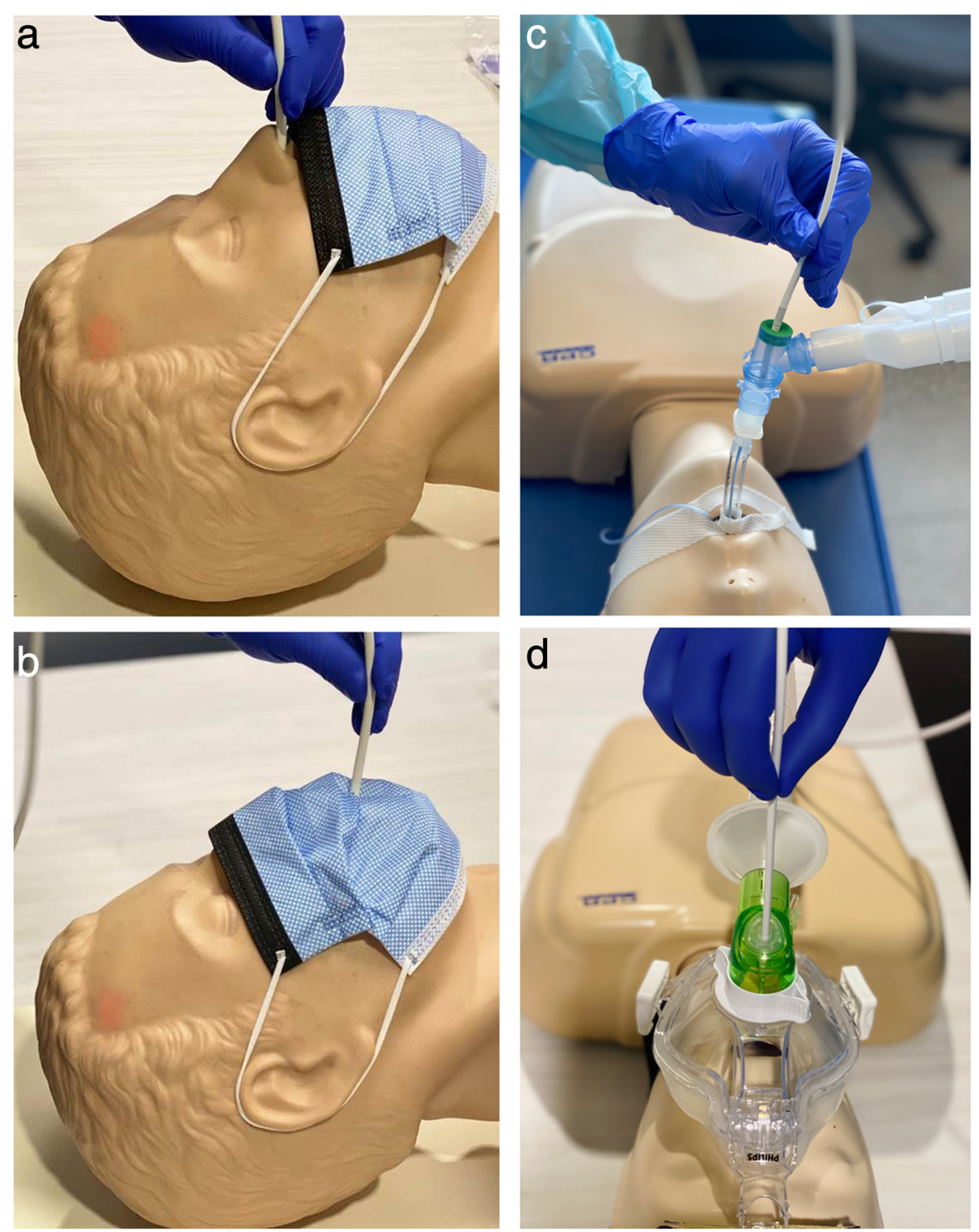

Fig. 7 a Bronchoscope insertion via the nose. b Bronchoscope insertion via the mouth. $\mathbf{c}$ Bronchoscope insertion via the endotracheal tube. d Bronchoscope insertion via the NIV mask 
manual ventilation, which is similar to the distance between clinicians and the patient's airway [41]. Placing a filter between resuscitator and mask (Fig. 5) has been found to significantly reduce the exhaled gas dispersion distance $[41,43,81]$.

For patients requiring mechanical ventilation via artificial airways, a ventilator with a dual-limb, heated wire circuit in conjunction with filters placed at the ventilator exhalation outlet is crucial [61, 73]. In addition, breaking the ventilator circuit connection should be limited and circuit changes should only be done when visibly soiled [82].

Approximately $8-13 \%$ mechanically ventilated patients receive tracheostomy to facilitate the long-term need for ventilatory support [83]. For patients with COVID-19, open tracheostomy is recommended over percutaneous dilational tracheostomy to reduce the risk of aerosol transmission [84]. Recently, Pichi et al. described standard steps to promote a safe and effective method when performing open tracheostomy in patients with COVID19 [85]. Bertroche et al. [86] created a negative pressure cover to limit the exposure to the aerosols, but these methods need further investigation on the efficacy in reducing nosocomial infections.

When transporting a mechanically ventilated COVID19 patient, it is suggested that a filter HME be placed between the artificial airway and the transport ventilator circuit [53]. Before pausing the ICU ventilator, consider clamping the endotracheal tube (ETT) to prevent derecruitment and minimize the spread of bio-aerosols when transitioning patients from the ICU ventilator to the transport ventilator $[5,87,88]$. When returning to the ICU, clamp the ETT and leave the filter connected to it to prevent accidental exposure. When ready for transition to the ICU ventilator, disconnect the bacteria filter and place the patient on the ventilator before unclamping ETT.

\section{Weaning and extubation}

The most common methods to perform a spontaneous breathing trial are T-piece trial and pressure support ventilation (PSV). Subirà and colleagues [89] reported that successful extubation occurred in $82.3 \%$ of patients in the PSV group compared to $74.0 \%$ in the T-piece group (difference, 8.2\%; 95\% CI, 3.4-13.0\%; $P=0.001$ ). With these findings, in conjunction with the need to avoid opening patient's airway to the environment, PSV is preferred for COVID-19 patients. When a T-piece is needed, HCWs should take safety precautions to minimize the exposure to a patient's airway, such as using the in-line suction catheter's T-piece with one end connecting humidified oxygen while the other end is connected to a filter (Fig. 6). This setup can also be applied for tracheostomy patients who are weaned from mechanical ventilation, particularly for patients who need frequent suctioning (more than once an hour), as this device keeps airway sealed and the filter protects HCWs during suctioning. However, the filter can be clogged as it captures water vapor; hence periodically checking and replacing the filter are necessary. A filter HME can also be used to provide passive humidity [90] while humidified oxygen via a tracheostomy mask should be avoided. Additionally, if the patient has a cuffless tracheostomy tube in place, a procedure mask on patient's face may reduce bio-aerosol dispersion.

The process of extubation induces a cough reflex which may spread aerosols; therefore, it is imperative to use proper precautions when removing an ETT [91]. During extubation, it is important to maintain the connection of the ventilator circuit and suction catheter to the ETT, in order to avoid aerosol dispersion from the ventilator circuit. The extubation procedure should be performed by two HCWs. In an in vitro study, a clear plastic drape was shown to significantly reduce aerosol dispersion during the extubation process; however, the feasibility of this practice requires further investigation [92].

\section{Bronchoscopy assist}

Bronchoscopy examination is considered an AGMP and may be related to an increased risk for transmission of infectious airborne particles [19]. Thompson et al. [45] found that bronchoscopy was associated with increased probability of aerosol generation and increased viral copies among different AGMPs for H1N1-positive patients. O'Neil et al [44] found an increase in particle concentration when a nebulized medication administration was performed before and after bronchoscopy, while bronchoscopy examination itself did not increase concentration compared to baseline.

According to the American Association for Bronchology and Interventional Pulmonology guidelines, bronchoscopy procedures are relatively contraindicated for patients with suspected or confirmed COVID-19 infections when less invasive diagnostic procedures are inconclusive [93]. Urgent bronchoscopy procedures should only be considered if intervention is deemed as lifesaving in patients with (1) massive hemoptysis, (2) benign or malignant severe airway obstruction, (3) suspicion of secondary infectious etiology, or (4) malignant condition that results in endobronchial obstruction. In the event a COVID-19 patient requires bronchoscopic intervention, it is recommended that the patient be placed in negative pressure isolation room and personnel should don appropriate droplet precaution PPE, including a powered air-purifying respirator or N95 mask [93].

Some additional precautions might also be considered to protect HCWs from exposure during bronchoscopy 
[94, 95]. (1) For spontaneously breathing patients, if the bronchoscope is inserted via the nares, a surgical or procedure mask should be placed to cover the face (Fig. 7a). If inserted via the mouth with a bite-block, a surgical or procedure mask with a small hole cut for bronchoscope insertion should be placed on the patient's face (Fig. 7b). (2) For non-invasively ventilated patients, a special NIV mask with an examination port should be used (Fig. 7d). (3) For invasively ventilated patients, a swivel adapter should be used to facilitate the bronchoscope insertion and to maintain ventilation (Fig. 7c).

\section{Pulmonary function testing}

Due to the risk of patient coughing and deep breathing during the procedure, pulmonary function testing is considered a platform for COVID-19 transmission. As a result, the American Thoracic Society recommends limiting testing to only those with immediate treatment needs [95] and, if possible, testing should only be performed upon symptom improvement and negative realtime polymerase chain reaction tests [96]. When performing pulmonary function tests, HCWs should adhere to strict infection control measures and use high specification disposable in-line viral/bacterial filters (minimum proven efficiency for high expiratory flow of 600 to 700 $\mathrm{L} / \mathrm{min}$ ) with the mouthpiece [97, 98]. When performing lung function testing in high-risk patients, the European Respiratory Society recommends that lung function testing should be limited to spirometry and diffusion capacity test. They also recommend the use of negative pressure rooms, when available [99]. Currently, there is limited data available if spirometry is an aerosolproducing procedure; therefore, HCWs should adhere to wearing full PPE [100].

\section{Conclusion}

The frontline HCWs are at risk for contracting the COVID-19 disease when caring for patients and providing aerosol-generating procedures. Until further high-quality studies generate robust evidence, defining the precise nosocomial transmission risk associated with AGMPs, along with CDC's recommended PPE guidelines, we propose additional respiratory protective measures that could reduce the nosocomial transmission of COVID-19 diseases to HCWs providing respiratory interventions.

\footnotetext{
Abbreviations

AGMP: Aerosol-generating medical procedure; ARDS: Acute respiratory distress syndrome; CDC: Centers for Disease Control and Prevention; Cl: Confidence interval; COVID-19: Coronavirus disease; ETT: Endotracheal tube; H1N1: Influenza A virus subtype H1N1; HCW: Healthcare worker; HFNC: High-flow nasal cannula; HME: Heat moisture exchanger; HME-F: HME with HEPA filtering; ICU: Intensive care unit; IPPB: Intermittent positive pressure breathing; MERS: Middle East respiratory syndrome; NIV: Noninvasive ventilation; PPE: Personal protective equipment; PSV: Pressure support ventilation; RR: Relative risk; SARS: Severe acute respiratory syndrome; SVN: Small volume nebulizer
}

\section{Acknowledgements}

We would like to thank J. Brady Scott for his assistance with the final review of the manuscript.

\section{Authors' contributions}

$J L, R K, T W$, and AP prepared the manuscript. JF, SM, RC, FL, and ZL reviewed and edited the manuscript. The authors read and approved the final manuscript.

\section{Funding}

Not applicable

Availability of data and materials

Not applicable

Ethics approval and consent to participate

Not applicable

\section{Consent for publication}

Tyler Weiss gives his consent to use his image in Fig. 3a.

\section{Competing interests}

Dr. Fink is the Chief Science Officer for Aerogen Pharma Corp. Dr. Li declares receiving unrestricted research grants from Fisher \& Paykel Healthcare Ltd and Rice Foundation. Other authors have no conflict of interests to declare.

\section{Author details}

${ }^{1}$ Division of Respiratory Care, Department of Cardiopulmonary Sciences, Rush University Medical Center, 1620 W Harrison St, Tower LL1202, Chicago, IL 60612, USA. ${ }^{2}$ Shenzhen Institute of Respiratory Disease, Shenzhen People's Hospital (First Affiliated Hospital of South University of Science and Technology of China), Shenzhen, China. ${ }^{3}$ Department of Respiratory and Critical Care Medicine, West China Medical Center of Sichuan University, Chengdu, China.

Received: 4 May 2020 Accepted: 7 August 2020

Published online: 23 September 2020

\section{References}

1. World Health Organization. Coronavirus disease 2019 (COVID-19) situation report - 1. Accessed 22 Mar 2020.

2. World Health Organization. Coronavirus disease 2019 (COVID-19) situation report - 141. Accessed 9 June 2020.

3. World Health Organization. Transmission of SARS-CoV-2: implications for infection prevention precautions. 2020. https://www.who.int/news-room/ commentaries/detail/transmission-of-sars-cov-2-implications-for-infectionprevention-precautions. Accessed 13 July 2020.

4. Liu Y, Ning Z, Chen Y, et al. Aerodynamic analysis of SARS-CoV-2 in two Wuhan hospitals. Nature. 2020; https://doi.org/10.1038/s41586-020-2271-3.

5. Dhand R, Li J. Coughs and sneezes: their role in transmission of respiratory viral infections, including SARS-CoV-2 [published online ahead of print, 2020 Jun 16]. Am J Respir Crit Care Med. 2020; https://doi.org/10.1164/rccm.202004-1263PP.

6. Huang C, Wang Y, Li X, et al. Clinical features of patients infected with 2019 novel coronavirus in Wuhan, China. Lancet. 2020;395:497-506.

7. Wang D, Hu B, Hu C, et al. Clinical characteristics of 138 hospitalized patients with 2019 novel coronavirus-infected pneumonia in Wuhan, China. JAMA. 2020;323(11):1061-9.

8. Chen N, Zhou M, Dong $X$, et al. Epidemiological and clinical characteristics of 99 cases of 2019 novel coronavirus pneumonia in Wuhan, China: a descriptive study. Lancet. 2020;395(10223):507-13.

9. Yang $X, Y u Y, X u$ J, et al. Clinical course and outcomes of critically ill patients with SARS-CoV-2 pneumonia in Wuhan, China. Lancet Respir Med. 2020:S2213-2600(20)30079-5.

10. Arentz M, Yim E, Klaff L, et al. Characteristics and outcomes of 21 critically ill patients with COVID-19 in Washington state. JAMA. Published online March. 2020;19. https://doi.org/10.1001/jama.2020.4326.

11. Grasselli G, Zangrillo A, Zanella A, et al. Baseline characteristics and outcomes of 1591 patients infected with SARS-CoV-2 admitted to ICUs of the Lombardy region, Italy [published online ahead of print, $2020 \mathrm{Apr} 6$ ]. JAMA. 2020;323(16):1574-81 https://doi.org/10.1001/jama.2020.5394. 
12. Richardson S, Hirsch JS, Narasimhan M, et al. Presenting characteristics, comorbidities, and outcomes among 5700 patients hospitalized with COVID-19 in the New York City area. JAMA. 2020;323(20):2052-9.

13. Seto $W H$, Tsang $D$, Yung RW, et al. Effectiveness of precautions against droplets and contact in prevention of nosocomial transmission of severe acute respiratory syndrome (SARS). Lancet. 2003;361(9368):1519-20.

14. Scales DC, Green K, Chan AK, et al. Illness in intensive care staff after brief exposure to severe acute respiratory syndrome. Emerg Infect Dis. 2003;9(10): 1205-10 https://doi.org/10.3201/eid0910.030525.

15. Chu DK, Akl EA, Duda S, et al. Physical distancing, face masks, and eye protection to prevent person-to-person transmission of SARS-CoV-2 and COVID-19: a systematic review and meta-analysis. Lancet 2020; published online June 1. https://doi.org/10.1016/S0140-6736(20)31142-9.

16. Gamage B, Moore D, Copes R, Yassi A, Bryce E, BC Interdisciplinary Respiratory Protection Study Group. Protecting health care workers from SARS and other respiratory pathogens: a review of the infection control literature. Am J Infect Control. 2005;33(2):114-21.

17. Suwantarat N, Apisarnthanarak A. Risks to healthcare workers with emerging diseases: lessons from MERS-CoV, Ebola, SARS, and avian flu. Curr Opin Infect Dis. 2015;28(4):349-61.

18. Raboud J, Shigayeva A, McGeer A, et al. Risk factors for SARS transmission from patients requiring intubation: a multicentre investigation in Toronto, Canada. PLoS One. 2010;5(5):e10717.

19. Judson SD, Munster VJ. Nosocomial transmission of emerging viruses via aerosol-generating medical procedures. Viruses. 2019;11(10):940.

20. Tran K, Cimon K, Severn M, Pessoa-Silva CL, Conly J. Aerosol generating procedures and risk of transmission of acute respiratory infections to healthcare workers: a systematic review. PLoS One. 2012;7(4):e35797.

21. Hui DS, Chan MT, Chow B. Aerosol dispersion during various respiratory therapies: a risk assessment model of nosocomial infection to health care workers. Hong Kong Med J. 2014;20(Suppl 4):9-13.

22. Macintyre $\mathrm{CR}$, Seale $H$, Yang $P$, et al. Quantifying the risk of respiratory infection in healthcare workers performing high-risk procedures. Epidemiol Infect. 2014;142(9):1802-8.

23. Center for Disease Control and Prevention. Coronavirus disease 2019. Cases, data and surveillance. https://www.cdc.gov/coronavirus/2019-ncov/casesupdates/cases-in-us.html. Accessed 10 July 2020.

24. Hui DS, Chow BK, Chu L, et al. Exhaled air dispersion and removal is influenced by isolation room size and ventilation settings during oxygen delivery via nasal cannula. Respirology. 2011;16(6):1005-13.

25. Ip M, Tang JW, Hui DS, et al. Airflow and droplet spreading around oxygen masks: a simulation model for infection control research. Am J Infect Control. 2007;35(10):684-9.

26. Hui DS, Ip M, Tang JW, et al. Airflows around oxygen masks: a potential source of infection? Chest. 2006;130(3):822-6.

27. Hui DS, Hall SD, Chan MT, et al. Exhaled air dispersion during oxygen delivery via a simple oxygen mask. Chest. 2007;132(2):540-6.

28. Hui DS, Chow BK, Chu L, et al. Exhaled air dispersion during coughing with and without wearing a surgical or N95 mask. PLoS One. 2012;7(12):e50845.

29. Milton DK, Fabian MP, Cowling BJ, Grantham ML, McDevitt JJ. Influenza virus aerosols in human exhaled breath: particle size, culturability, and effect of surgical masks. PLoS Pathog. 2013;9(3):e1003205

30. Johnson DF, Druce JD, Birch C, Grayson ML. A quantitative assessment of the efficacy of surgical and N95 masks to filter influenza virus in patients with acute influenza infection. Clin Infect Dis. 2009;49(2):275-7.

31. Leung $\mathrm{CCH}$, Joynt GM, Gomersall CD, et al. Comparison of high-flow nasal cannula versus oxygen face mask for environmental bacterial contamination in critically ill pneumonia patients: a randomized controlled crossover trial. J Hosp Infect. 2019;101(1):84-7.

32. Wang K, Zhao W, Li J, Shu W, Duan J. The experience of high-flow nasal cannula in hospitalized patients with 2019 novel coronavirus-infected pneumonia in two hospitals of Chongqing, China. Ann Intensive Care. 2020; 10(1):37 Published 2020 Mar 30. https://doi.org/10.1186/s13613-020-00653-z.

33. Hui DS, Chow BK, Chu LCY, et al. Exhaled air and aerosolized droplet dispersion during application of a jet nebulizer. Chest. 2009;135(3):648-54.

34. McGrath JA, O'Sullivan A, Bennett $G$, et al. Investigation of the quantity of exhaled aerosols released into the environment during nebulisation. Pharmaceutics. 2019;11(2):75 Published 2019.

35. Simonds AK, Hanak A, Chatwin M, et al. Evaluation of droplet dispersion during non-invasive ventilation, oxygen therapy, nebuliser treatment and chest physiotherapy in clinical practice: implications for management of pandemic influenza and other airborne infections. Health Technol Assess. 2010;14(46):131-72.

36. Lee J, Yoo D, Ryu S, et al. Quantity, size distribution, and characteristics of cough-generated aerosol produced by patients with an upper respiratory tract infection. Aerosol Air Qual Res. 2019;19(4):840-53.

37. Hui DS, Hall SD, Chan MT, et al. Noninvasive positive-pressure ventilation: an experimental model to assess air and particle dispersion. Chest. 2006;130(3):730-40.

38. Hui DS, Chow BK, Ng SS, et al. Exhaled air dispersion distances during noninvasive ventilation via different Respironics face masks. Chest. 2009; 136(4):998-1005

39. Fowler RA, Guest CB, Lapinsky SE, et al. Transmission of severe acute respiratory syndrome during intubation and mechanical ventilation. Am J Respir Crit Care Med. 2004;169(11):1198-202.

40. Cheung TM, Yam LY, So LK, et al. Effectiveness of noninvasive positive pressure ventilation in the treatment of acute respiratory failure in severe acute respiratory syndrome. Chest. 2004;126(3):845-50.

41. Chan MTV, Chow BK, Lo T, et al. Exhaled air dispersion during bag-mask ventilation and sputum suctioning - implications for infection control. Sci Rep. 2018;8(1):198.

42. Cai SJ, Wu LL, Chen DF. et al, Analysis of bronchoscope-guided tracheal intubation in 12 cases with COVID-19 under the personal protective equipment with positive pressure protective hood. Chin J Tuberc Respir Dis. 2020;43 Epub ahead of print. https://doi.org/10.3760/cma.j.cn11214720200222-00153.

43. Christian MD, Loutfy M, McDonald LC, et al. Possible SARS coronavirus transmission during cardiopulmonary resuscitation. Emerg Infect Dis. 2004; 10(2):287-93 https://doi.org/10.3201/eid1002.030700.

44. O'Neil CA, Li J, Leavey A, et al. Characterization of aerosols generated during patient care activities. Clin Infect Dis. 2017;65(8):1335-41.

45. Thompson K, Pappachan JV, Bennett AM, Mittal H, Macken S, Dove BK, et al. Influenza aerosols in UK hospitals during the H1N1 (2009) pandemic - the risk of aerosol generation during medical procedures. PLoS One. 2013;8(2):e56278.

46. Weber TP, Stilianakis NI. Inactivation of influenza A viruses in the environment and modes of transmission: a critical review. J Inf Secur. 2008;57(5):361-73.

47. Lindsley WG, Blachere FM, Beezhold DH, et al. Viable influenza A virus in airborne particles expelled during coughs versus exhalations. Influenza Other Respir Viruses. 2016;10(5):404-13.

48. Stilianakis NI, Drossinos Y. Dynamics of infectious disease transmission by inhalable respiratory droplets. J R Soc Interface. 2010;7(50):1355-66.

49. Jensen PA, Lambert LA, lademarco MF, Ridzon R, CDC. Guidelines for preventing the transmission of Mycobacterium tuberculosis in health-care settings, 2005. MMWR Recomm Rep. 2005;54(RR-17):1-141.

50. Bean B, Moore BM, Sterner B, Peterson LR, Gerding DN, Balfour HH Jr. Survival of influenza viruses on environmental surfaces. J Infect Dis. 1982;146(1):47-51.

51. van Doremalen N, Bushmaker T, Morris DH, Holbrook MG, Gamble A, Williamson BN, et al. Aerosol and surface stability of SARS-CoV-2 as compared with SARS-CoV-1. N Engl J Med. Published online 2020 Mar 17. https://doi.org/10.1056/NEJMc2004973.

52. Center for Disease Control and Prevention. https://www.cdc.gov/coronavirus/2 019-ncov/hcp/infection-control-recommendations.html\#take_precautions.

53. Li J, Fink JB, Ehrmann S. High-flow nasal cannula for COVID-19 patients: low risk of bio-aerosol dispersion. Eur Respir J. 2020;55(5):2000892.

54. Somogyi $R$, Vesely $A E$, Azami $T$, et al. Dispersal of respiratory droplets with open vs closed oxygen delivery masks: implications for the transmission of severe acute respiratory syndrome. Chest. 2004;125(3):1155-7.

55. Li J, Jing GQ, Scott JB. Year in review 2019: high-flow nasal cannula (HFNC) oxygen therapy for adult patients. Respir Care. 2020;65(4):545-57.

56. Rochwerg B, Granton D, Wang DX, et al. High flow nasal cannula compared with conventional oxygen therapy for acute hypoxemic respiratory failure: a systematic review and meta-analysis. Intensive Care Med. 2019;45(5):563-72.

57. Patel M, Gangemi A, Marron R, et al. Use of high flow nasal therapy to treat moderate to severe hypoxemic respiratory failure in COVID-19. medRxiv 2020.05.22.20109355. https://doi.org/10.1101/2020.05.22.20109355.

58. Hui DS, Chow BK, Lo T, et al. Exhaled air dispersion during high flow nasal cannula therapy versus CPAP via different masks. Eur Respir J. 2019;53:1802339.

59. Leonard S, Atwood CW Jr, Walsh BK, et al. Preliminary findings on control of dispersion of aerosols and droplets during high-velocity nasal insufflation therapy using a simple surgical mask: implications for the high-flow nasal cannula [published online ahead of print, 2020 Apr 2]. Chest. 2020; https:// doi.org/10.1016/j.chest.2020.03.043 
60. Sandrock C, Stollenwerk N. Acute febrile respiratory illness in the ICU: reducing disease transmission. Chest. 2008;133(5):1221-31.

61. Zhonghua Jie He He Hu Xi Za Zhi. Expert Consensus on Preventing Nosocomial Transmission During Respiratory Care for Critically III Patients Infected by 2019 Novel coronavirus pneumonia. Chin J Tuberc Respir Dis. 2020; 17 Epub ahead of print. https://doi.org/10.3760/cma.j.issn.1001-0939.2020.0020.

62. Keeley D. Everyone with asthma should have a metered dose inhaler and a spacer. BMJ. 2018;360:k648.

63. Baudin F, Buisson A, Vanel B, Massenavette B, Pouyau R, Javouhey E. Nasal high flow in management of children with status asthmaticus: a retrospective observational study. Ann Intensive Care. 2017;7(1):55

64. Li J, Harnois LJ, Markos B, et al. Epoprostenol delivered via high flow nasal cannula for ICU subjects with severe hypoxemia comorbid with pulmonary hypertension or right heart dysfunction. Pharmaceutics. 2019;11(6):281.

65. Li J, Gurnani PK, Roberts KM, Fink JB, Vines D. The clinical impact of flow titration on epoprostenol delivery via high flow nasal cannula for ICU patients with pulmonary hypertension or right ventricular dysfunction: a retrospective cohort comparison study. J Clin Med. 2020;9(2):464.

66. Li J, Gong L, Fink JB. The ratio of nasal cannula gas flow to patient inspiratory flow on trans-nasal pulmonary aerosol delivery for adults: an in vitro study. Pharmaceutics. 2019;11(5):225.

67. Li J, Gong L, Ari A, Fink JB. Decrease the flow setting to improve trans-nasal pulmonary aerosol delivery via "high-flow nasal cannula" to infants and toddlers. Pediatr Pulmonol. 2019;54(6):914-21.

68. Patel BK, Wolfe KS, PohIman AS, Hall JB, Kress JP. Effect of noninvasive ventilation delivered by helmet vs face mask on the rate of endotracheal intubation in patients with acute respiratory distress syndrome: a randomized clinical trial. JAMA. 2016;315(22):2435-41.

69. Bellani G, Laffey JG, Pham T, et al. Noninvasive ventilation of patients with acute respiratory distress syndrome. Insights from the LUNG SAFE study. Am J Respir Crit Care Med. 2017;195(1):67-77.

70. Alraddadi BM, Qushmaq I, Al-Hameed FM, et al. Noninvasive ventilation in critically ill patients with the Middle East respiratory syndrome. Influenza Other Respir Viruses. 2019;13(4):382-90.

71. Hui DS, Chow BK, Lo T, et al. Exhaled air dispersion during noninvasive ventilation via helmets and a total facemask. Chest. 2015;147(5):1336-43.

72. Cheung JC, Ho LT, Cheng JV, Cham EYK, Lam KN. Staff safety during emergency airway management for COVID-19 in Hong Kong [published online ahead of print, 2020 Feb 24]. Lancet Respir Med. 2020;\$22132600(20):30084-9 https://doi.org/10.1016/S2213-2600(20)30084-9.

73. Wax RS, Christian MD. Practical recommendations for critical care and anesthesiology teams caring for novel coronavirus (2019-nCoV) patients. Can J Anaesth. 2020; https://doi.org/10.1007/s12630-020-01591-X.

74. Yao W, Wang $T$, Jiang $B$, et al. Emergency tracheal intubation in 202 patients with COVID-19 in Wuhan, China: lessons learnt and international expert recommendations [published online ahead of print, $2020 \mathrm{Apr} 10]$ ]. $\mathrm{Br}$ J Anaesth. 2020; S0007-0912(20)30203-8.

75. Yam LY, Chen RC, Zhong NSSARS. ventilatory and intensive care. Respirology. 2003;8(Suppl):S31-5.

76. Zuo MZ, Huang YG, Ma WH. et al, Expert recommendations for tracheal intubation in critically ill patients with noval coronavirus disease 2019 [published online ahead of print, 2020 Feb 27]. Chin Med Sci J. 2020; https://doi.org/10.24920/003724.

77. Canelli R, Connor CW, Gonzalez M, Nozari A, Ortega R. Barrier enclosure during endotracheal intubation. N Engl J Med. 2020;382(20):1957-8.

78. Chen C, Shen N, Li X, Zhang Q, Hei Z. New device and technique to protect intubation operators against COVID-19 [published online ahead of print, 2020 May 8]. Intensive Care Med. 2020:1-3 https://doi.org/10.1007/s00134020-06072-9.

79. Coronavirus disease 2019 (COVID-19): anesthetic concerns, including airway management and infection control. UpToDate. 2020. https://www.uptodate. com/contents/coronavirus-disease-2019-covid-19-airway-managementanesthesia-machine-ventilation-and-anesthetic-care. opens in new tab.

80. Jhou HJ, Chen PH, Lin C, Yang LY, Lee CH, Peng CK. High-flow nasal cannula therapy as apneic oxygenation during endotracheal intubation in critically ill patients in the intensive care unit: a systematic review and metaanalysis. Sci Rep. 2020;10(1):3541.

81. Chan MT, Chow BK, Chu L, Hui DS. Mask ventilation and dispersion of exhaled air. Am J Respir Crit Care Med. 2013;187(7):e12-4.

82. Han J, Liu Y. Effect of ventilator circuit changes on ventilator-associated pneumonia: a systematic review and meta-analysis. Respir Care. 2010;55(4):467-74.
83. Mehta AB, Syeda SN, Bajpayee L, Cooke CR, Walkey AJ, Wiener RS. Trends in tracheostomy for mechanically ventilated patients in the United States, 1993-2012. Am J Respir Crit Care Med. 2015;192(4):446-54.

84. Chao TN, Braslow BM, Martin ND, et al. Tracheotomy in ventilated patients with COVID-19 [published online ahead of print, 2020 May 5]. Ann Surg. 2020; https://doi.org/10.1097/SLA.0000000000003956.

85. Pichi B, Mazzola F, Bonsembiante A, et al. CORONA-steps for tracheotomy in COVID-19 patients: a staff-safe method for airway management. Oral Oncol 2020;105:104682. https://doi.org/10.1016/j.oraloncology.2020.104682.

86. Bertroche JT, Pipkorn P, Zolkind P, Buchman CA, Zevallos JP. Negativepressure aerosol cover for COVID-19 tracheostomy [published online ahead of print, 2020 Apr 28]. JAMA Otolaryngol Head Neck Surg. 2020:e201081 https://doi.org/10.1001/jamaoto.2020.1081.

87. Turbil E, Terzi N, Schwebel C, Cour M, Argaud L, Guérin C. Does endotracheal tube clamping prevent air leaks and maintain positive endexpiratory pressure during the switching of a ventilator in a patient in an intensive care unit? A bench study. PLoS One. 2020;15(3):e0230147.

88. Li YC, Lin HL, Liao FC, et al. Potential risk for bacterial contamination in conventional reused ventilator systems and disposable closed ventilatorsuction systems. PLoS One. 2018;13(3):e0194246.

89. Subirà $C$, Hernández $G$, Vázquez $A$, et al. Effect of pressure support vs Tpiece ventilation strategies during spontaneous breathing trials on successful extubation among patients receiving mechanical ventilation: a randomized clinical trial [published correction appears in JAMA. 2019 Aug 20;322(7):696]. JAMA. 2019;321(22):2175-82.

90. De Seta D, Carta F, Puxeddu R. Management of tracheostomy during COVID-19 outbreak: heat and moisture exchanger filter and closed suctioning system [published online ahead of print, 2020]. Oral Oncol. 2020: 104777 https://doi.org/10.1016/j.oraloncology.2020.104777.

91. Jee D, Park SY. Lidocaine sprayed down the endotracheal tube attenuates the airway-circulatory reflexes by local anesthesia during emergence and extubation. Anesth Analg. 2003;96(1) https://doi.org/10.1097/00000539200301000-00058

92. Matava CT, Yu J, Denning S. Clear plastic drapes may be effective at limiting aerosolization and droplet spray during extubation: implications for COVID19. Can J Anaesth. 2020;67(7):902-4.

93. Wahidi MM, Lamb C, Murgu S, et al. American Association for Bronchology and Interventional Pulmonology (AABIP) statement on the use of bronchoscopy and respiratory specimen collection in patients with suspected or confirmed COVID-19 infection. March 19 ${ }^{\text {th }}$ Updates. Accessed on 20 Mar 2020 at https://aabronchology.org/2020/03/12/2020-aabipstatement-on-bronchoscopy-covid-19-infection/.

94. Respiratory Care Committee of Chinese Thoracic Society. Expert consensus on preventing nosocomial transmission during respiratory care for critically ill patients infected by 2019 novel coronavirus pneumonia. Zhonghua Jie He He Hu Xi Za Zhi. 2020;43(4):288-96.

95. Ferioli M, Cisternino C, Leo V, Pisani L, Palange P, Nava S. Protecting healthcare workers from SARS-CoV-2 infection: practical indications. Eur Respir Rev. 2020;29(155):200068.

96. ATS, Pulmonary function laboratories: advice regarding COVID-19. 2020 https://www.thoracic.org/professionals/clinical-resources/disease-related resources/pulmonary-function-laboratories.php. Accessed 29 Mar 2020.

97. Bignamini E, Cazzato $S$, Cutrera $R$, et al. Italian pediatric respiratory society recommendations on pediatric pulmonary function testing during COVID19 pandemic. Ital J Pediatr. 2020;46:68.

98. Zhi ZJHHHXZ, et al. Task force of Pulmonary Function Testing and Clinical Respiratory Physiology, Chinese Association of Chest Physicians; Pulmonary Function Testing Group, Respiratory Therapeutics Group. Chin Thorac Soc. 2020;43(4):302-7.

99. Recommendation from ERS Group 9.1 (Respiratory function technologists /Scientists) Lung function testing during COVID-19 pandemic and beyond. https://ers.app.box.com/s/zs1uu88wy51monr0ewd990itoz4tsn2h. Accessed 10 July 2020.

100. Hull JH, Lloyd JK, Cooper BG. Lung function testing in the COVID-19 endemic. Lancet Respir Med. 2020;8(7):666-7.

\section{Publisher's Note}

Springer Nature remains neutral with regard to jurisdictional claims in published maps and institutional affiliations. 